\title{
CHLOROPROCAINE-BUPIVACAINE SEQUENCE FOR OBSTETRIC EXTRADURAL ANALGESIA
}

\author{
Evelyn A. Villa and Gertie F. Marx*
}

Bupivacaine (Marcaine ${ }^{\circledR}$ ) is probably the safest long-acting local anaesthetic drug for extradural analgesia in obstetrics at the present time. Like lidocaine (Xylocaine ${ }^{(8)}$ ) and mepivacaine (Carbocaine ${ }^{\circledR}$ ), it is an amide-linkage drug and, as such, is degraded by hepatic microsomal enzymes, which are not present in full quantity in the neonate. However, because of its high protein-binding property, transfer of bupivacaine across the human placenta is only approximately one-half that of lidocaine or mepivacaine. ${ }^{1}$ Consequently, no decrease in muscle tone, muscle strength, or reflex activity has been found in newborns whose mothers received an extradural block with bupivacaine, ${ }^{2}$ whereas long-lasting muscle effects have been demonstrated following equipotent doses of the other two amide-type local anaesthetics. ${ }^{3}$ Slow onset of action is one major disadvantage of bupivacaine in obstetric practice. After caudal administration of 0.25 per cent of the drug to 99 parturient women, Moore and his associates ${ }^{4}$ found a mean interval of $5.9 \pm 2.5$ minutes to onset of analgesia and $19.7 \pm 8.3$ minutes to maximum anaesthesia. When a 0.5 per cent solution was employed in 108 obstetric patients, onset of analgesia occurred $6.4 \pm 4.1$ minutes later and maximum anaesthesia did not ensue until $24.7 \pm$ 11.2 minutes. ${ }^{4}$

Delay in effect is inappropriate in most obstetric situations. Prompt pain relief is desirable in rapid labour and essential in emergent operative deliveries. Such prompt analgesia can be attained by a combined technique, i.e., by initiating the extradural block with 2-chloroprocaine (Nesacaine ${ }^{\circledR}$ ), an ester-linkage local anaesthetic characterized by almost immediate onset of action as well as by rapid hydrolysis through plasma cholinesterase activity. In vitro studies by Finster et al. ${ }^{5}$ demonstrated a half-life for chloroprocaine of 21 seconds in venous blood from term-pregnant women, making placental transfer of clinically significant amounts of drug unlikely. Moreover, the half-life in foetal blood, although longer, was only 43 seconds, confirming the fact that the normal newborn infant possesses adequate plasma cholinesterase activity.

A chloroprocaine-bupivacaine sequence offers two additional advantages. First, because of the ready regradation, two or even three "test" doses of chloroprocaine may be used with impunity in rapid succession, an important consideration in a teaching program. Second, the "balanced" administration of two local anaesthetics with different metabolic patterns reduces the dosage of each, thus increasing the safety of the block in case of unsuspected liver dysfunction or cholinesterase abnormality.

The following two case reports illustrate the rationale of a chloroprocainebupivacaine sequence in obstetric extradural block.

'Department of Anesthesiology, Albert Einstein College of Medicine. Bronx, New York 10461. Mail correspondence to: Gertie F. Marx, M.D., Department of Anesthesiology, Albert Einstein College of Medicine, 1300 Morris Park Avenue, Bronx, New York 10461, U.S.A. 


\section{CASE REPORTS}

Case 1. A lumber extradural block was started in a secundipara at 7-cm dilation of the cervix. With the patient in the right lateral recumbent position, a 17-gauge thin-walled Tuohy needle was inserted, the extradural space identified by loss of resistance, and a test dose of $3 \mathrm{ml}$ of 2 per cent chloroprocaine injected. The catheter was then threaded in a cephalad direction, but shortly after passing the tip of the needle, it became "trapped" and could not be advanced further, necessitating removal of both needle and catheter. The patient being in active labour, a singleinjection technique was decided upon. The needle was reinserted (in the same interspace), and the test dose of $3 \mathrm{ml}$ of 2 per cent chloroprocaine was repeated. Two minutes later, $7 \mathrm{ml}$ of 2 per cent chloroprocaine were added. This was followed by elevation of the head of the bed and injection of $10 \mathrm{ml}$ of 0.25 per cent bupivacaine. The patient was then turned supine, with a wedge raising the right hip. Sensory analgesia from T 9 through $\mathrm{L} 2$ developed within four minutes, perineal anaesthesia within 13 minutes. The patient had complete pain relief for the last part of labour ( 25 minutes), delivery and repair of episiotomy ( 45 minutes).

Case 2. A primipara in active labour was scheduled for caesarean section because of cephalopelvic disproportion. Although there was no immediate emergency, the operation was to be undertaken with expediency. With the patient in the right lateral recumbent position, the extradural space was identified, and a test dose of $2 \mathrm{ml}$ of 3 per cent chloroprocaine was administered. Then $10 \mathrm{ml}$ of 3 per cent chloroprocaine were added, and a catheter was threaded cephalad. The patient was turned supine with left uterine displacement. Five minutes after the injection of the chloroprocaine, analgesia was adequate for operation. During the two-hour course of operation, the patient received two doses of 0.5 per cent bupivacaine through the catheter for maintenance of analgesia.

\section{SUMMARY}

Two case reports, one a vaginal delivery, the other a Caesarean Section, have been presented to demonstrate the rationale of employing a chloroprocaine-bupivacaine sequence for extradural analgesia in obstetrics. Use of chloroprocaine for initiation and bupivacaine for maintenance of the block offers at least three advantages:

(1) onset of pain relief is prompt while duration is prolonged;

(2) more than one "test" dose of chloroprocaine may be employed with safety in rapid succession;

(3) two drugs with different metabolic patterns are used, each in reduced amount.

\section{RÉSUMÉ}

Nous avons rapporté deux cas, un d'accouchement par voie vaginale et une césarienne, pour démontrer l'avantage de la combinaison chloroprocaine-bupivacaine en sequence durant l'analgésie extradurale en obstétrique. L'emploi de la chloroprocaine au début suivi par la bupivacaine présente trois avantages:

(1) le début de l'analgésie est rapide et la durée prolongée; 
(2) la "test dose" de chloroprocaine peut être répété sans danger à plusieurs reprises rapprochées;

(3) deux drogues qui ont différentes voies de metabolisms sont employées à doses reduites.

\section{REFERENCES}

1. Tucker, G.T., Boyes, R.N., Bridenbaugh, P.O., \& Moore, D.C. Binding of anilide-type local anesthetics in human plasma. II. Implications in vivo, with special reference to transplacental distribution. Anesthesiology 33: 304-314 (1970).

2. Scanlon, J.W., Brown, W.U., Weiss, J.B., \& Alper, M.H. Neurobehavioral responses of newborn infants after maternal epidural anesthesia. Anesthesiology 40:121-128 (1974).

3. Scanlon, J.W., Brown, W.U., \& Ostheimer, G.W. Neurobehavioral responses of newborns after maternal epidural anesthesia with bipuvacaine. Abstracts of Scientific Papers, Annual Meeting, Society for Obstetric Anesthesia and Perinatology (1974).

4. Moohe, D.C., Bridenbaugh, L.D., Bhidenbaugh, P.O., \& Tucker, G.T. Bupivacaine. A review of 2,077 cases. JAMA 214: 713-718 (1970).

5. Finster, M., Perel, J.M., Hinsvark, O.N., \& O'Brien, J.E. Reassessment of the metabolism of 2-chloroprocaine hydrochloride (Nesacaine(1)). Abstracts of Scientific Papers, Annual Meeting, American Society of Anesthesiologists (1973). 